\title{
Adaptability and Stability in Maize Populations
}

\author{
Jeeder Fernando Naves Pinto ${ }^{1}$, Willame dos Santos Candido $^{1}$, Jefferson Fernando Naves Pinto ${ }^{1}$ \\ \& Edésio Fialho dos Reis ${ }^{1}$ \\ ${ }^{1}$ Universidade Federal de Goiás, Jataí, State of Goiás, Brazil \\ Correspondence: Edésio Fialho dos Reis, Universidade Federal de Goiás, Regional Jataí, BR 364 km 194 n \\ 3800, 75800-000 Jataí, State of Goiás, Brazil. Tel: 55-649-988-6935. E-mail: edesiofr7@gmail.com
}

\author{
Received: April 24, $2019 \quad$ Accepted: June 6, $2019 \quad$ Online Published: August 31, 2019 \\ doi:10.5539/jas.v11n14p23 URL: https://doi.org/10.5539/jas.v11n14p23
}

\begin{abstract}
Maize plays an important role in the national and global economy, continuously increasing its total production due to advances in technology and access to new land areas. Thus, new sources of germplasm are fundamental to generate cultivars more adapted to the diversity of environments and planting times. The objective of this study was to evaluate 36 populations of maize in three environments, aiming to identify the existence of genotype-by-environment interaction, classify populations based on adaptability and stability using the methods of regression and mixed models, indicate the best populations, and compare the two methodologies. The environments evaluated were: E1-second crop (safrinha) season of 2016 in an experimental area of latosol, with incidence of water stress; E2-crop season 2016/2017 in sandy soil, in family farm area; and E3-crop season 2016/2017 in an experimental area of latosol, no incidence of water stress. Grain yield was evaluated, adaptability and stability analysis was performed. Population 36 achieved high productivity, adaptability and general stability in three tested environments. Both methodologies showed similar results regarding adaptability and stability of some populations in three environments, but mixed models were more suitable for providing better selective accuracy.
\end{abstract}

Keywords: genotype $\times$ environment interaction, germplasm, mixed models, plant breeding, Zea mays

\section{Introduction}

In plant breeding, effects of genotype-by-environment interaction $(\mathrm{G} \times \mathrm{E})$, adaptability and stability parameters are very important because each cultivar has an inherent capacity with response to changes in environments (Scapim et al., 2010). Therefore, identification of genotypes with high productive potential and wide adaptability and stability is one of the main targets in maize breeding programs (Faria et al., 2017).

In the maize breeding program, the breeder must plan actions that, in the presence of complex interactions, allow the development of specific cultivars for a specific environment. Thus, it is important to know the type of interaction and genotypes generated due to changes in the environment.

However, the existence of $\mathrm{G} \times \mathrm{E}$ interaction is a great disadvantage in the selection of genotypes with high production capacity across different environments, since a strong interaction makes selection difficult. This is because genotypes that perform well in an environment may not perform so well in other environments or even the occurrence of change in the population order due to change in the study environment in the presence of complex interaction. Thus, performance of genotypes across breeding stages should be evaluated in different environments to reduce the chance of misleading recommendations. Therefore, besides high productivity, the new cultivars should have yield stability and adaptability, or suitability for the target regions. Studies of adaptability and stability parameters contribute greatly as they provide information on the behavior of each genotype under different environmental conditions (Mendes et al., 2012). Different conditions of soil and climate, site of cultivation, crop year, technology level (Scapim et al., 2000), and other factors can be considered as distinct environments.

Several methods have been developed to evaluate adaptability and stability, and it is worth mentioning the methodology of mixed models proposed by Resende (2002). The method takes into account errors correlated within each environment, provides genetic values already penalized by instability and capitalized by adaptability, and allows selection by three attributes at the same time (productivity, stability, and adaptability) (Faria et al., 2017). Because of the soil variability in the municipality of Jataí, with great predominance of Latosol, Cambisols and Argisols, which together exceed $90 \%$ of the total area of the municipality (Hermuche, Guimarães, \& Castro, 
2009); the variability of planting times (crop and second crop) of maize; and production systems with small, medium, and large farms, it is necessary to implement breeding programs that focus on the peculiarities of these areas.

Therefore, the objectives of this study were to evaluate the behavior of different populations of maize in three contrasting environments, aiming to identify the existence of genotype by environments interaction for grain production, classify the populations for adaptability and stability using regression and mixed models, indicate the best populations to form a composite variety, and compare the two methodologies.

\section{Method}

\subsection{Experimental Conditions and Experimental Design}

Planting was carried out in three contrasting environments: Environment 1 (E1): Latosol with $22.09 \%$ of sand, $16.86 \%$ of silt, and $61.06 \%$ of clay, planting on February 18, 2016 (second crop), with severe water stress during the crop cycle (Figure 1); Environment 2 (E2): Sandy soil with $86.82 \%$ of sand, $3.47 \%$ of silt, and $9.71 \%$ of clay, planting on November 26, 2016; and Environment 3 (E3): Latosol with $22.09 \%$ of sand, $16.86 \%$ of silt, and $61.06 \%$ of clay, planting on November 23, 2016 (Table 1). The crops in E2 and E3 were conducted in crop year with normal water regime (Figure 2). The experiments were arranged in a randomized block design with four replicates. The plots consisted of two rows of five meters with plants spaced $0.90 \mathrm{~m}$ between rows and $0.20 \mathrm{~m}$ within rows.

Table 1. Characterization of the environments (E1, E2, E3) used for evaluation of 36 populations of maize (Zea mays) in Jataí, Goiás, BR

\begin{tabular}{|c|c|c|c|c|c|}
\hline Environments & Planting Time & Soil & Sand $\%$ & Silt $\%$ & Clay $\%$ \\
\hline E1 & 18 February 2016-Second crop season 2016 & Latosol & 22.09 & 16.86 & 61.06 \\
\hline E2 & 26 November 2016-Crop season 2016/17 & Sandy & 86.82 & 3.47 & 9.71 \\
\hline E3 & 23 November 2016-Crop season 2016/17 & Latosol & 22.09 & 16.86 & 61.06 \\
\hline
\end{tabular}

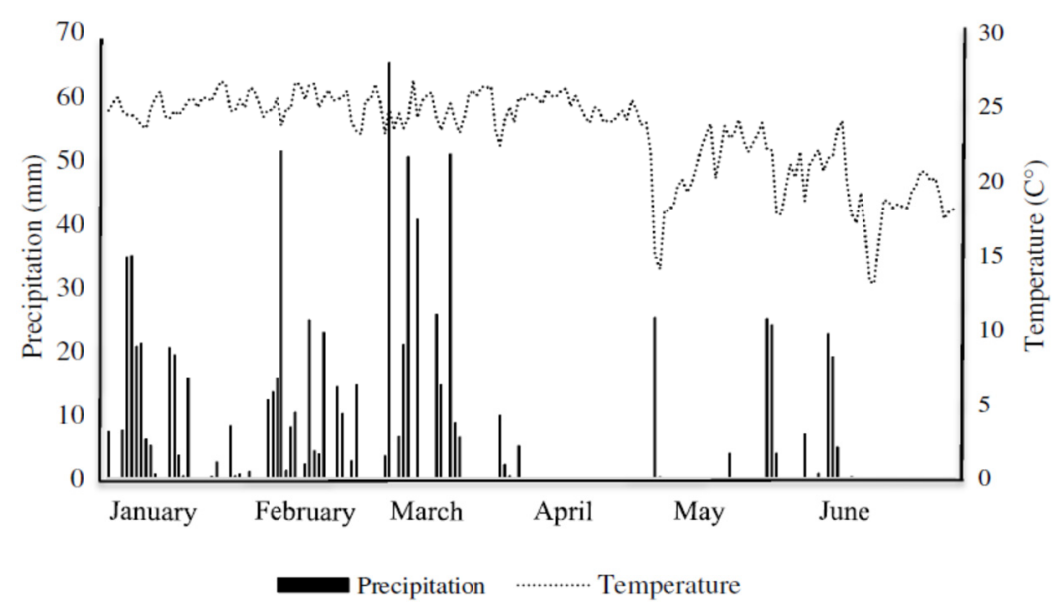

Figure 1. Precipitation and temperature data in Jataí-Goiás, January to June 2016 (environments E1). Jataí/GO 


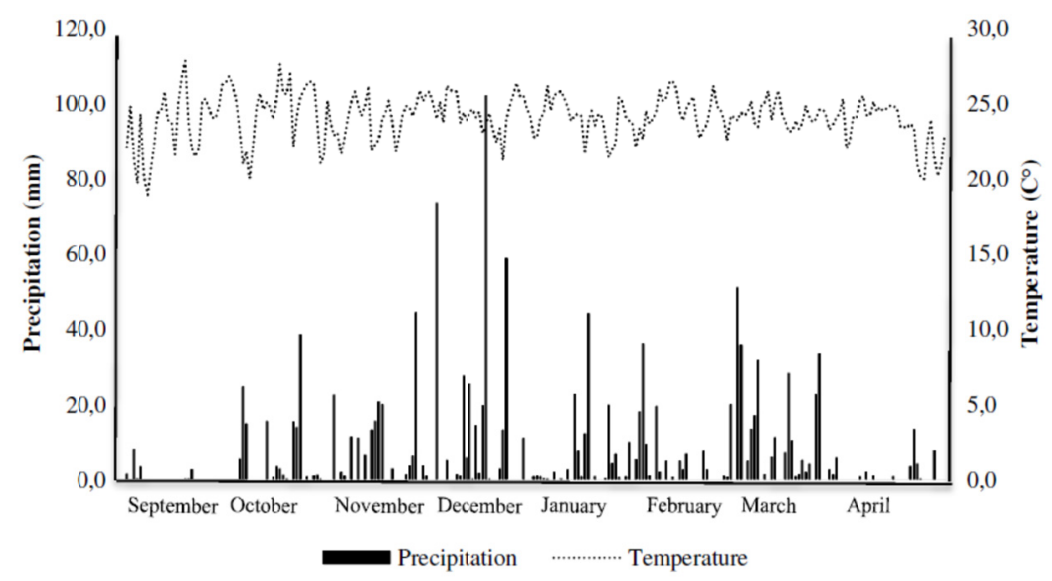

Figure 2. Precipitation and temperature data in Jataí-Goiás, September to April 2016 (environments E2 and E3). Jataí/GO

\subsection{Plant Materials and Treatments}

Thirty-six populations of maize were evaluated, including: 17 populations derived from the assessment of partly self-fertilized progenies in a top cross 1 to 14: Top-cross hybrids (1to5: selected for higher grain yield; 6 to10: selected for lower relative spike height; 5 and 11to14: selected for greater multiple disease tolerance); synthetics produced by the three selection strategies (29: recombination of 5 best-performing $\mathrm{S}_{2}$ families for leaf disease tolerance; 30: recombination of 5 best-performing $S_{2}$ families for grain production; 31: recombination of $5 S_{2}$ families for low relative spike height); 14 populations derived from composites formed by partial diallel between commercial hybrids and semiexotic populations (15 to 23: composite under usual crop season; 19 to 22 and 24 to 28: composite under second crop; the populations CRE-01 (35) and TGMV (36) from the UFG-Jataí breeding program; and 3 controls: a modified commercial hybrid; a conventional commercial hybrid; and an open-pollinated variety (32: Modified Hybrid-30S31H; 33: Conventional Hybrid-AG1051; 34: Commercial Variety-Al-Bandeirantes).

\subsection{Conduction of Study and Traits Measured}

Fertilization was applied in topdressing, according to soil analysis, using the NPK formula 04-20-18. Two fertilizer applications were carried out: the first, at V4, with NPK formula 20-00-20; and the second, a week later, with ammonium sulphate. For pest control, seeds were treated with the insecticide fipronil and two applications of Diflubenzuron at 20 and 35 days after sowing. Weed control was done with two applications of $240 \mathrm{~mL}$ tembotrione and $3 \mathrm{~L} \mathrm{ha}^{-1}$ atrazine during post emergence of maize and weeds at 20 and 35 days after sowing.

At harvest, plants per plot (stand) were counted and grain yield was obtained from the total yield of each plot and corrected to $\mathrm{kg} \mathrm{ha}^{-1}$ with $13 \%$ moisture. Grain weight was adjusted to optimum stand of 50 plants according to the covariance method of Vencosvsky and Barriga (1992).

\subsection{Statistical Anlysis}

Maize grain yield was examined by analyses of variance performed for each of the three environments followed by the analysis of joint variance and the F-test at $1 \%$ of probability.

The adaptability and stability parameters were estimated according to the methodology of Eberhart and Russell (1966), using the Genes program (Cruz, 2013) and the Selegen-REML/BLUP (model 54) software (Resende, 2016).

The harmonic mean of the relative performance of the genotypic values (HMRPGV) model mistos was used for the evaluation of stability, adaptability, and yield, was calculated for all genotypes according to the following expressions (Resende, 2002):

$$
\begin{gathered}
\text { MHPRVG }=\frac{\mathrm{I}}{\sum_{\mathrm{i}=1}^{\mathrm{I}} \frac{1}{\text { PRVGj }}} \\
\text { PRVG }=\frac{1}{\mathrm{I}}\left(\frac{\sum \mathrm{VGj}}{\mathrm{Mj}}\right)
\end{gathered}
$$

where, I is the number of environments; VG is the genotypic value; and $\mathrm{j}$ represent the genotypes. 


\section{Results and Discussion}

\subsection{Analysis of Variance}

The analysis of variance showed significant effects of the genotype and environment interaction for grain yield (Table 2), indicating different responses of the genotypes to the studied environments. Similar results for maize grain yield were reported by Cargnelutti Filho, Storck, Riboldi, and Guadagnin, (2009); Faria, Viana, Mundim, Silva, and Câmara (2010); Scapim et al. (2010); Mendes et al. (2012); Oliveira, Moreira, and Ferreira, (2013) and Faria et al. (2017), confirming the importance of adaptability and stability analysis. The method of Eberhart and Russell (1966) classified the environments 1 and 2 as unfavorable (negative environmental index) for grain production, the environment 3 as favorable (positive environmental index) (Table 3 ).

Table 2. Joint analyses of variance of 36 populations of maize (Zea mays) evaluated for grain yield in three environments (E1, E2 and E3), Jataí, Goiás, BR

\begin{tabular}{lll}
\hline \multirow{2}{*}{$\mathrm{SV}$} & \multicolumn{2}{c}{ Grain yield } \\
\cline { 2 - 3 } & $\mathrm{Df}$ & $\mathrm{SM}$ \\
\hline Block/Environment & 9 & 2.03 \\
Population (G) & 35 & $1.576^{* *}$ \\
Environment (E) & 2 & $401.302^{* *}$ \\
$\mathrm{G} \times \mathrm{E}$ & 70 & $2.718^{* *}$ \\
Error & 315 & 0.265 \\
Mean & 3.706 & \\
$\mathrm{CV} \%$ & 13.898 & \\
\hline
\end{tabular}

Note. ${ }^{* *}$ Significant at $1 \%$ probability by the F test. Df: Degrees of freedom; SM: Square Middle; SV: Source of Variation.

Table 3. Environment classification, using the environmental index method of Eberhart and Russell (1966), of the 36 populations of maize (Zea mays) evaluated for grain yield $\left(\mathrm{kg} \mathrm{ha}^{-1}\right)$ in three environments, in Jataí-GO, in the second crop 2015/2016 and in the crop year 2016/2017

\begin{tabular}{lllll}
\hline Environment * & Mean & Index $\left(\mathrm{I}_{\mathrm{j}}\right)$ & Maximum & Minimum \\
\hline Environment 1 & 2.714 & -0.993 & 3.083 & 2.218 \\
Environment 2 & 2.771 & -0.935 & 3.860 & 1.753 \\
Environment 3 & 5.633 & 1.927 & 7.730 & 3.970 \\
\hline
\end{tabular}

Note. * Environment 1: second crop 2015/2016-occurrence of water stress; Environment 2: crop year 2016/2017-soil with 86.82\% sand; Environment 3: crop year 2016/2017-soil of medium texture.

\subsection{Method of Eberhart and Russell (Adaptability and Stability)}

The method of Eberhart and Russell (1966) uses the parameters "regression coefficient" $\left(\beta_{1 \mathrm{i}}\right)$ to evaluate genotype adaptability and "regression deviation" $\left(\sigma_{\mathrm{di}}^{2}\right)$ to evaluate the stability, which indicates the predictability of the genotypes to changes in the environment (Rios et al., 2009).

The genotypes 16, 24 (Table 4) had regression coefficient greater than unity $\left(\beta_{1 \mathrm{i}}\right)$ and non-significant regression deviation, showing adaptation to favorable environments and predictability of behavior (Scapim et al., 2010). The control genotypes 33 and 34 had the same classification, however, the genotype 34 (a commercial variety) showed significant regression deviation, indicating low predictability. These genotypes are among the best behavior per se for productivity. Genotypes $6,9,10,11$ and 31 had regression coefficient lesser than unity $\left(\beta_{1 \mathrm{i}}\right)$ and non-significant regression deviation, demonstrating their adaptation to unfavorable environments and predictability of behavior, however, as shown by the productivity mean (Table 4), they are genotypes of inferior behavior per se. The other genotypes showed regression coefficient equal to unity (non-significant $\left(\beta_{1 \mathrm{i}}\right)$ ), which characterizes adaptability to all environments (Scapim et al., 2010) and non-significant regression deviation, indicating predictability of behavior in the environments, except for the commercial hybrid (genotype 31), with low predictability. According to Cardoso et al. (2012), these analyses aim to identify genotypes that are adapted, stable, and productive, allowing recommendation according to the environment of interest. 
Table 4. Estimates of adaptability and stability parameters according to the method of Eberhart and Russell (1966) and stability and adaptability of genotypic values (MHPRVG) for grain yield in 36 populations of maize (Zea mays L.) evaluated in three environments, in Jataí-GO, second crop season 2015/2016 and crop season 2016/2017

\begin{tabular}{|c|c|c|c|c|c|c|c|}
\hline Population order ${ }^{1 /}$ & Mean & $\beta_{1}$ & $\sigma_{\mathrm{di}}^{2}$ & $\mathrm{R}^{2}(\%)$ & Population order $^{2 /}$ & MHPRVG & MHPRVG·MG \\
\hline 34 & 4.703 & $1.578^{* *}$ & $0.719^{* *}$ & 94.642 & 34 & 1.191 & 4.414 \\
\hline 36 & 4.270 & 1.112 & $-0.042^{\mathrm{ns}}$ & 99.649 & 36 & 1.132 & 4.195 \\
\hline 16 & 4.260 & $1.244^{*}$ & $0.099^{\mathrm{ns}}$ & 98.119 & 16 & 1.118 & 4.144 \\
\hline 33 & 4.220 & $1.330^{* *}$ & $-0.066^{\mathrm{ns}}$ & 99.996 & 33 & 1.103 & 4.088 \\
\hline 24 & 4.127 & $1.230^{*}$ & $-0.005^{\mathrm{ns}}$ & 99.273 & 24 & 1.088 & 4.032 \\
\hline 18 & 4.027 & 1.033 & $0.088^{\mathrm{ns}}$ & 97.475 & 18 & 1.074 & 3.983 \\
\hline 30 & 3.997 & 1.204 & $0.021^{\mathrm{ns}}$ & 98.932 & 25 & 1.060 & 3.931 \\
\hline 25 & 3.953 & 1.025 & $-0.064^{\mathrm{ns}}$ & 99.958 & 30 & 1.055 & 3.912 \\
\hline 22 & 3.927 & 1.045 & $-0.009^{\mathrm{ns}}$ & 99.063 & 22 & 1.051 & 3.895 \\
\hline 4 & 3.897 & 1.035 & $-0.077^{\mathrm{ns}}$ & 99.028 & 4 & 1.043 & 3.867 \\
\hline 26 & 3.880 & 1.048 & $-0.066^{\mathrm{ns}}$ & 99.999 & 26 & 1.038 & 3.849 \\
\hline 17 & 3.840 & 1.132 & $-0.055^{\mathrm{ns}}$ & 99.835 & 7 & 1.030 & 3.819 \\
\hline 7 & 3.833 & 1.025 & $-0.065^{\mathrm{ns}}$ & 99.978 & 1 & 1.023 & 3.791 \\
\hline 1 & 3.817 & 1.047 & $-0.038^{\mathrm{ns}}$ & 99.544 & 17 & 1.021 & 3.786 \\
\hline 35 & 3.797 & 1.154 & $-0.063^{\mathrm{ns}}$ & 99.958 & 35 & 1.010 & 3.444 \\
\hline 27 & 3.757 & 1.043 & $-0.055^{\mathrm{ns}}$ & 99.808 & 27 & 1.008 & 3.738 \\
\hline 15 & 3.753 & 1.180 & $-0.053^{\mathrm{ns}}$ & 99.827 & 2 & 1.006 & 3.730 \\
\hline 2 & 3.733 & 0.975 & $-0.006^{\mathrm{ns}}$ & 98.868 & 28 & 1.004 & 3.722 \\
\hline 28 & 3.703 & 0.902 & $-0.017^{\mathrm{ns}}$ & 98.918 & 15 & 0.997 & 3.694 \\
\hline 8 & 3.697 & 1.069 & $-0.036^{\mathrm{ns}}$ & 99.532 & 8 & 0.991 & 3.673 \\
\hline 32 & 3.613 & 1.073 & $0.316^{*}$ & 94.373 & 3 & 0.978 & 3.624 \\
\hline 3 & 3.610 & 0.961 & $-0.022^{\mathrm{ns}}$ & 99.145 & 13 & 0.972 & 3.605 \\
\hline 20 & 3.553 & 1.156 & $-0.061^{\mathrm{ns}}$ & 99.924 & 32 & 0.964 & 3.573 \\
\hline 13 & 3.550 & 0.821 & $-0.062^{\mathrm{ns}}$ & 99.878 & 11 & 0.960 & 3.558 \\
\hline 12 & 3.547 & 1.041 & $-0.050^{\mathrm{ns}}$ & 99.713 & 14 & 0.958 & 3.552 \\
\hline 21 & 3.540 & 1.022 & $-0.051^{\mathrm{ns}}$ & 99.736 & 12 & 0.956 & 3.543 \\
\hline 14 & 3.507 & 0.852 & $-0.009^{\mathrm{ns}}$ & 98.594 & 21 & 0.955 & 3.539 \\
\hline 11 & 3.457 & $0.677^{* *}$ & $-0.036^{\mathrm{ns}}$ & 98.832 & 20 & 0.946 & 3.508 \\
\hline 19 & 3.370 & 1.095 & $-0.066^{\mathrm{ns}}$ & 99.992 & 31 & 0.943 & 3.494 \\
\hline 31 & 3.370 & $0.567^{*}$ & $-0.050^{\mathrm{ns}}$ & 99.080 & 10 & 0.910 & 3.373 \\
\hline 23 & 3.303 & 0.879 & $-0.017^{\mathrm{ns}}$ & 98.871 & 19 & 0.906 & 3.361 \\
\hline 5 & 3.270 & 0.798 & $-0.053^{\mathrm{ns}}$ & 99.635 & 23 & 0.906 & 3.360 \\
\hline 10 & 3.207 & $0.395^{*}$ & $-0.025^{\mathrm{ns}}$ & 95.462 & 5 & 0.905 & 3.355 \\
\hline 6 & 3.187 & $0.614^{* *}$ & $-0.052^{\mathrm{ns}}$ & 99.326 & 9 & 0.896 & 3.323 \\
\hline 9 & 3.183 & $0.603^{* *}$ & $-0.065^{\mathrm{ns}}$ & 99.921 & 6 & 0.896 & 3.322 \\
\hline 29 & 2.983 & 1.034 & $0.072^{\mathrm{ns}}$ & 97.739 & 29 & 0.808 & 2.997 \\
\hline
\end{tabular}

Note. $\beta_{0}=$ regression constant, $\beta_{1}=$ regression coefficient, $\sigma_{\mathrm{di}}^{2}=$ regression deviation, $\mathrm{R}^{2}=$ coefficient of determination. ${ }^{* *},{ }^{*}$ : significantly different from 1 , by $\mathrm{t}$ test, at $1 \%$ and $5 \%$ probability, respectively. ${ }^{* *},{ }^{*}$ : significantly different from 0 , by $\mathrm{F}$ test, at $1 \%$ and $5 \%$ probability, respectively. ${ }^{\text {ns }}$ : non significant.

${ }^{1 /}$ : Order based on the average of the three environments.

${ }^{2 /}$ : Order based on the method of mixed models.

\subsection{Mixed Model Methodology to Test Genotype's Adaptability and Stability}

The mixed model methodology (Resende, 2016) was used for the simultaneous selection of genotypes based on productivity, adaptability, and stability. The harmonic mean of the relative performance of the genotypic value (MHPRVG) (Table 4), which infers about the expected productivity, adaptability, and stability of genotypes, was estimated (Silva, Carvalho, Vieira, \& Benin, 2011; Rosado, Rosado, Alves, Laviola, \& Bhering, 2012). This estimate (MHPRVG) can be used when considering planting in several locations with different $\mathrm{G} \times \mathrm{E}$ interactions. Therefore, we should seek genotypes with the MHPRVG greater than or equal to 1 (Torres, Teodoro, Sagrilo, Ceccon, \& Correa, 2015; Carvalho, Farias, Moewllo, \& Teodoro, 2016). We found that among the five genotypes 
with the highest MHPRVG $(34,36,16,33,24)$, four are indicated by the Eberhart and Russell method for favorable environments and good predictability of behavior (Table 4). Genotype 36 is the only one that appears among those indicated for favorable environments and with good predictability, all with good behavior per se.

The MHPRVG method was applied separately for the favorable and unfavorable environments. To do so, we divided the three environments into two groups, based on the grain yield of each environment. Environments with yield above the overall mean $\left(3,710 \mathrm{~kg} \mathrm{ha}^{-1}\right)$ were classified as favorable and those with mean yields below the overall mean were classified as unfavorable. Mendes et al. (2012), and Oliveira, Atroch, Dias, Guimarães, and Guimarães (2017) evaluated maize adaptability and stability in favorable and unfavorable environments and showed that this classification is important in the selection of genotypes with adaptability to specific environments. Of the three environments evaluated, two (environment 1 and environment 2) were classified as unfavorable, and one (environment 3 ) as favorable.

Figure 3 shows the scatter plot of genotype performance measured by MHPRVG·MG, combining productivity, adaptability, and stability. This allowed the identification of stable materials that are widely adapted to different environments (favorable and unfavorable). Populations were found with good adaptability and yield stability for different environments. The seven populations that had the best MHPRVG·MG in favorable environment were, in descending order: $34,33,16,24,36,30$, and 15 , indicating populations with good productivity, adaptability, and stability for these environments. However, genotypes 36,34 , and 16 , showed the best behavior in unfavorable environment. On the other hand, genotypes 20,32, 15, 8, and 35 showed good productivity in favorable environments, and had low productivity in the unfavorable environment and, thus, they can be classified as having adaptability specific to favorable environments.

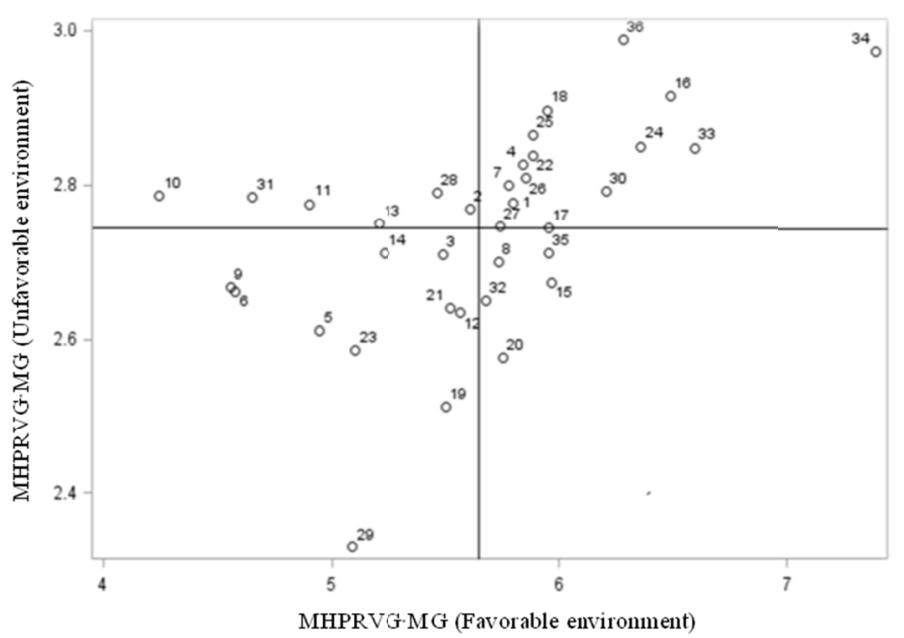

Figure 3. MHPRVG·MG scatter plot for grain yield $\left(\mathrm{kg} \mathrm{ha}^{-1}\right)$ of 36 maize populations in favorable (E3) and unfavorable environments (E1 and E2)

\subsection{Estimate the Genetic Parameters}

Individual broad-sense heritabilities increased across the unfavorable environments 1 and 2, and the favorable environment 3 (Table 5). The mean heritability of the genotypes across the environments and blocks was higher in the favorable environment. Accuracy, which indicates the experimental precision, was estimated at $64.6 \%$ and $61.6 \%$ for the favorable and unfavorable environment, respectively, showing that experimental precision increases with improvement of the environment. According to Pimentel et al. (2014), the greater the selective accuracy in the evaluation of an individual, the greater the confidence in the assessment and the genetic value predicted for the individual. Similarly, Mendes et al. (2012), and Oliveira, Atroch, Dias, Guimarães, and Guimarães (2017), studying adaptability and stability of maize cultivars, found that heritability and accuracy increased in the favorable environment compared with the unfavorable environment, corroborating the results of this study.

The genotypic correlation between the performances across the environments was moderate (Table 5). The correlations of $50 \%$ for favorable environment and $53.9 \%$ for unfavorable environment indicate a coincidence of 50 to $54 \%$ in the selection of genotypes specific for each environment, that is, if we were to select genotypes in each environment, in environment 3 , the coincidence of this selection across the environments would be $50 \%$. 
These correlations result in the presence of the complex part of the $\mathrm{G} \times \mathrm{E}$ interaction and complicate the selection of genotypes with larger adaptation, as it is observed by Mendes et al. (2012), Faria et al. (2017), and Oliveira, Atroch, Dias, L. J. Guimarães, and P. E. O. Guimarães (2017).

Table 5. Estimates of variance components (individual REML) for comparison of unfavorable environments (E1 and E2) with favorable environment (E3)

\begin{tabular}{|c|c|c|c|}
\hline \multicolumn{4}{|c|}{ Variance components (individual REML) } \\
\hline \multicolumn{2}{|c|}{ Unfavorable environment } & \multicolumn{2}{|c|}{ Favorable environment } \\
\hline $\mathrm{V}_{\mathrm{g}}$ & 0.022 & $\mathrm{~V}_{\mathrm{g}}$ & 0.237 \\
\hline $\mathrm{V}_{\text {int }}$ & 0.019 & $V_{\text {int }}$ & 0.237 \\
\hline $\mathrm{V}_{\mathrm{e}}$ & 0.211 & $\mathrm{~V}_{\mathrm{e}}$ & 0.373 \\
\hline$V_{f}$ & 0.252 & $\mathrm{~V}_{\mathrm{f}}$ & 0.848 \\
\hline$h_{g}^{2}$ & $0.087 ; 0.049$ & $h_{g}^{2}$ & $0.279 ; 0.125$ \\
\hline $\mathrm{h}_{\mathrm{mg}}^{2}$ & 0.379 & $\mathrm{~h}_{\mathrm{mg}}^{2}$ & 0.418 \\
\hline$A_{\text {cgen }}$ & 0.616 & $A_{\text {cgen }}$ & 0.646 \\
\hline $\mathrm{c}_{\mathrm{int}}^{2}$ & 0.074 & $\mathrm{c}_{\text {int }}^{2}$ & 0.280 \\
\hline$r_{\text {gloc }}$ & 0.539 & $r_{\text {gloc }}$ & 0.500 \\
\hline $\mathrm{CV}_{\mathrm{gi}} \%$ & 5.386 & $\mathrm{CV}_{\mathrm{gi}} \%$ & 8.648 \\
\hline $\mathrm{CV}_{\mathrm{e}} \%$ & 16.761 & $\mathrm{CV}_{\mathrm{e}} \%$ & 10.846 \\
\hline Overall mean & 2,740 & Overall mean & 5,630 \\
\hline
\end{tabular}

Note. $\left(\mathrm{V}_{\mathrm{g}}\right)$ : genotypic variance; $\left(\mathrm{V}_{\mathrm{int}}\right)$ : variance of genotype $\times$ environment interaction; $\left(\mathrm{V}_{\mathrm{e}}\right)$ : residual variance; $\left(\mathrm{V}_{\mathrm{f}}\right)$ : individual phenotypic variance; $\left(\mathrm{h}_{\mathrm{g}}^{2}=\mathrm{h}^{2}\right)$ : broad sense heritability of individual plots, i.e., total genotypic effects; $\left(\mathrm{c}_{\mathrm{int}}^{2}=\mathrm{c}^{2}\right)$ : coefficient of determination of the effects of genotype $\times$ environment interaction; $\left(\mathrm{h}_{\mathrm{mg}}^{2}\right)$ : heritability of the genotype mean, assuming complete survival; $\left(\mathrm{A}_{\text {cgen }}\right)$ : accuracy of genotype selection, assuming complete survival; $\left(\mathrm{r}_{\text {gloc }}\right)$ : genotypic correlation between performance in the environments; $\left(\mathrm{CV}_{\mathrm{gi}} \%\right)$ : genotypic coefficient of variation.; $\left(\mathrm{CV}_{\mathrm{e}} \%\right)$ : coefficient of residual variation.

\subsection{Favorable and Unfavorable Environments}

The overall mean grain yield of the 36 populations in the favorable and unfavorable environments were 5,630 and $2,740 \mathrm{~kg} \mathrm{ha}^{-1}$, respectively, showing a $100 \%$ increase in the yield of the favorable environment in relation to the unfavorable environment. The lower yield in the unfavorable environments can be explained by the long-term water deficit during the experiment in environment 1, in the second crop 2016, and the sandy soil in environment 2 , which is a limiting factor of productivity. Thus, the average yield of unfavorable environments is approximately $50 \%$ lower than the national average yield of maize in the crop season $2015 / 16$, which was 4,928 kg ha ${ }^{-1}$ (IBGE, 2016). The yield of environment 3 was approximately 14\% higher than the national average yield. These results demonstrate the importance of performing experiments in specific environments for selection of superior populations for specific environment conditions.

\subsection{Comparison of the Two Methodologies of Adaptability and Stability}

The MHPRVG method was suitable for the identification of maize genotypes with high productivity and wide adaptability and yield stability. There was similarity in the selection of some populations by the methodologies used in the three environments evaluated. The most productive, stable, and widely adaptable populations recommended by the method of Eberhart and Russell for environment 1 are 24, 36, 30, 25, and 7. These populations were also indicated as superior by the method of mixed models for the same environment. However, these methods disagree as to the selection of two populations: the method of Eberhart and Russell also selected populations 10 and 31, and the method of mixed models selected populations 16 and 26 .

For environment 2, the most productive, stable, and widely adaptable populations selected by the method of Eberhart and Russell are 16,36, 18, 22, 4, and 28. These populations were also indicated as superior by the method of mixed models for this environment. Again, these methods disagree regarding the selection of one population: the method of Eberhart and Russell also selected population 2, and the method of mixed models selected the population 25 .

The method of Eberhart and Russell recommended for the environment 3 the populations 16, 24, 36, 30, 35, and 17, as the most productive, stable and widely adaptable. The method of mixed models also indicated them as superior 
for this environment. The methods disagree on the selection of one population: the method of Eberhart and Russell selected the population 15, and the method of mixed models selected the population 18 .

Vasconcelos et al. (2015) points out that the use of more than one method to estimate the genetic parameters is a strategy that allows greater reliability in the interpretation of the data for later recommendation of cultivars.

\section{Conclusions}

The methods of Eberhart and Russell and Mixed Models showed similar classification of some populations regarding adaptability and stability in the three environments, but the method of mixed models is recommended for the indication of the best populations for providing better selective accuracy.

$\mathrm{G} \times \mathrm{E}$ interaction exists for the populations evaluated, with predominance of the complex type.

Population 36 is promising for breeding programs aimed at cultivars with greater adaptability and stability, since it was selected as superior in all environments.

The populations selected by the method of mixed models to form a composite to obtain new populations for future breeding actions for each environment are: environment E1: 36, 24, 30, 25, 16, 7, and 26; environment E2: 16, 36, $18,22,4,25$, and 28; and environment E3: 16, 24, 36, 30, 18, 17, and 35.

\section{References}

Cardoso, M. J., Carvalho, H. W. L. de, Rocha, L. M. P., Pacheco, C. A. P., Guimarães, L. J. M., Guimarães, P. E. O., ... Oliveira, I. R. (2012). Maize-cultivar identification based on phenotype-stability analysis in the Mid-Northern region of Brazil. Revista Ciência Agronômica, 43, 346-353. https://doi.org/10.1590/ S1806-66902012000200018

Cargnelutti Filho, A., Storck, L., Riboldi, J., \& Guadagnin, J. P. (2009). Association between adaptability and stability methods in corn. Ciência Rural, 39, 340-347. https://doi.org/10.1590/S0103-84782008005000080

Carvalho, L. P., Farias, F. J. C., Moewllo, C. L., \& Teodoro, P. E. (2016). Use of REML/BLUP methodology for selecting cotton genotypes with higher adaptability and productive stability. Bragantia, 75, 314-321. https://doi.org/10.1590/1678-4499.275

Cruz, C. D. (2013). GENES - A software package for analysis in experimental statistics and quantitative genetics. Acta Scientiarum. Agronomy, 35, 271-276. https://doi.org/10.4025/actasciagron.v35i3.21251

Eberhart, S. A., \& Russell, W. A. (1966). Stability parameters for comparing varieties. Crop Science, 6, 36-40. https://doi.org/10.2135/cropsci1966.0011183X000600010011x

Faria, S. V., Luz, L. S., Rodrigues, M. C., Carneiro, J. E. de S., Carneiro, P. C. S., \& Lima, R. O. (2017). Adaptability and stability in commercial maize hybrids in the southeast of the State of Minas Gerais, Brazil. Revista Ciência Agronomica, 48, 347-357. https://doi.org/10.5935/1806-6690.20170040

Faria, V. R., Viana, J. M. S., Mundim, G. B., Silva, A. C., \& Câmara, T. M. M. (2010). Adaptability and stability of popcorn populations related through selection cycles. Pesquisa Agropecuária Brasileira, 45, 1396-1403. https://doi.org/10.1590/S0100-204X2010001200009

Hermuche, P. M., Guimarães, G. M. A., \& Castro, S. S. (2009). Análise dos compartimentos morfopedológicos como subsídio ao planejamento do uso do solo em Jataí-GO. GEOUSP: Espaço e Tempo, 26, 113-132. https://doi.org/10.11606/issn.2179-0892.geousp.2009.74131

IBGE (Instituto Brasileiro de Geografia e Estatística). (2016). Produção Agrícola Municipal/2016: Milho. Retrieved from https://www.ibge.gov.br/estatisticas/economicas/agricultura-e-pecuaria/9201-levantamentosistematico-da-producao-agricola.html? $=\& \mathrm{t}=\mathrm{o}$-que-e

Mendes, F. F., Guimarães, L. J. M., Souza, J. C., Guimarães, P. E. O., Pacheco, C. A. P., Machado, J. R. A., ... Parentoni, S. N. (2012). Adaptability and stability of maize varieties using mixed model methodology. Crop Breeding and Applied Biotechnology, 12, 111-117. https://doi.org/10.1590/S1984-70332012000200003

Oliveira, I. J., Atroch, A. L., Dias, M. C., Guimarães, L. J., \& Guimarães, P. E. O. (2017). Selection of corn cultivars for yield, stability, and adaptability in the state of Amazonas, Brazil. Pesquisa Agropecuária Brasileira, 52, 455-463. https://doi.org/10.1590/s0100-204x2017000600009

Oliveira, R. B. R., Moreira, R. M. P., \& Ferreira, J. M. (2013). Adaptability and stability of maize landrace varieties. Semina: Ciências Agrárias, 34, 2555-2564. https://doi.org/10.5433/1679-0359.2013v34n6p2555

Pimentel, A. J. B., Guimarães, J. F. R., Souza, M. A., Resende, M. D. V., Moura, L. M., Carvalho, J. R. A. S. C., \& Ribeiro, G. (2014). Estimation of genetic parameters and prediction of additive genetic value for wheat by 
mixed models. Pesquisa Agropecuária Brasileira, 49, 882-890. https://doi.org/10.1590/S0100-204X2014 001100007

Resende, M. D. V. (2002). Software Selegen-REML/BLUP. Brasília, Colombo: Embrapa Florestas.

Resende, M. D. V. (2016). Software Selegen-REML/BLUP: A useful tool for plant breeding. Crop Breeding and Applied Biotechnology, 16, 330-339. https://doi.org/10.1590/1984-70332016v16n4a49

Rios, S. A., Paes, M. C. D., Borém, A., Cruz, C. D., Guimarães, P. E. O., Schaffert, R. E., ... Pacheco, C. A. P. (2009). Adaptability and stability of caretenoids in maize cultivars. Crop Breeding and Applied Biotechnology, 9, 313-319. https://doi.org/10.12702/1984-7033.v09n04a05

Rosado, A. M., Rosado, T. B., Alves, A. A., Laviola, B. G., \& Bhering, L. L. (2012). Simultaneous selection of eucalyptus clones based on yield, stability and adaptability. Pesquisa Agropecuária Brasileira, 47, 964-971. https://doi.org/10.1590/S0100-204X2012000700013

Scapim, C. A., Oliveira, V. R., Braccini, A. L., Cruz, C. D., Andrade, C. A. B., \& Vidigal, M. C. G. (2000). Yield stability in maize (Zea mays L.) and correlations among the parameters of the Eberhart and Russell, Lin and Binns and Huehn models. Genetics and Molecular Biology, 23, 387-393. https://doi.org/10.1590/S141547572000000200025

Scapim, C. A., Pacheco, C. A. P., Amaral Júnior, A. T., Vieira, R. A., Pinto, R. J. B., \& Conrado, T. V. (2010). Correlations between the stability and adaptability statistics of popcorn cultivars. Euphytica, 174, 209-218. https://doi.org/10.1007/s10681-010-0118-y

Silva, G. O., Carvalho, A. D. F., Vieira, J. V., \& Benin, G. (2011). Verification of the adaptability and stability of carrot populations by AMMI, GGE Biplot and REML/BLUP methods. Bragantia, 70, 494-501. https://doi.org/10.1590/S0006-87052011000300003

Torres, F. E., Teodoro, P. E., Sagrilo, E., Ceccon, G., \& Correa, A. M. (2015). Genotype $\times$ environment interaction in semiprostrade cowpea genotypes via mixed models. Bragantia, 74, 255-260. https://doi.org/10.1590/ 1678-4499.0099

Vasconcelos, F. M. T., Vasconcelos, R. A., Luz, L. N., Cabrali, N. T., Oliveira Junior, J. O. L., Santiago, A. D., ... Santos, R. C. (2015). Comparison of adaptability and stability estimates in upright peanut genotypes cultivated in Northeast and Midwest regions. Ciência Rural, 45, 1375-1380. https://doi.org/10.1590/ 0103-8478cr20140414

Vencovsky, R., \& Barriga, P. (1992). Genética biométrica no fitomelhoramento. Ribeirão Preto: Sociedade Brasileira de Genética.

\section{Copyrights}

Copyright for this article is retained by the author(s), with first publication rights granted to the journal.

This is an open-access article distributed under the terms and conditions of the Creative Commons Attribution license (http://creativecommons.org/licenses/by/4.0/). 